\title{
CURRENT TRENDS IN NURSING EDUCATION: FUNDAMENTALS OF STIMULATING TUTORING
}

\author{
Iryna Radziievska \\ Vice Rector for Academic Affairs, Cherkasy Medical Academy, Ukraine \\ e-mail: raisin03@ukr.net,orcid.org/0000-0002-5216-1928
}

\section{Summary}

The paper studies the relevance of implementing of the simulation tutoring in the process of training nurses, its importance in mastering knowledge and skills and forming professional preparation of graduates. The purpose of the article is to analyze the effectiveness of the methodology of simulation tutoring of future specialists at the stage of training in an educational institution. General scientific research methods were applied: generalization, study, systematization of scientific and pedagogical, methodological literature, periodicals, internet resources; practical experience of the center for stimulating training of Cherkasy Medical Academy was used to assess the effectiveness of simulation tutoring of future specialists in specialty 223 Nursing, the results of the study were substantiated and graphically reflected. It is proved that modern trends in nursing education allow applicants to learn and practice without risking the lives and health of patients. The results of the study indicate that nursing as a specialty occupies a stable place in the structure of medical personnel training, it is interesting and promising for young people, most of the graduates are satisfied with the quality of education that meets their needs and expectations, the obtained professional training is multi-faceted and will allow them to engage in various activities in the future. When forming educational programs and curricula of this specialty, particular attention should be paid to professional disciplines and more widely introduce simulation tutoring modules into the educational process of nurses.

Keywords: simulation tutoring, nursing education, educational trends, pre-graduate training.

DOI: https://doi.org/10.23856/4512

\section{Introduction}

Formulation of the problem. One of the problems of training specialists in medical educational institutions of Ukraine is a broad theoretical training combined with a low level of practical skills. This is influenced by many negative factors that have recently been observed in medical education: a low number of classrooms and a significant number of hours for self-study in the curriculum (up to $2 / 3$ of the total amount), the introduction of distance learning during a difficult epidemic situation caused by the COVID-19; a decrease in the motivation of educational applicants to their chosen profession due to lack of funds in the industry and low wages; conducting a licensed integrated exam at the pre-graduate stage of training. Preparation of applicants for the license exam is carried out by educational institutions during the final (graduate) year of study at the expense of hours allocated for classroom training and at the expense of hours of clinical educational and industrial (pre-graduate) practice. In addition, the traditional form of training provides for an average of up to five years of adaptation to the profession in clinics, not to mention social aspects (sequence of work functions, common interests, team interaction, common decision-making, which is not taught in a medical educational institution). 
The aim of the study was to assess the effectiveness of the method of simulation tutoring of future medical specialists at the stage of training in an educational institution and analyze the relationship between the level of their professional training (basic, medium complexity and high-tech skills) and socio-demographic characteristics (age, gender).

The research hypothesis contained the following assumptions:

1) the well-established opinion that it is possible to acquire skills only in the course of independent work at the patient's bedside sharply contradicts the world and domestic statistics of medical mistakes made by young specialists;

2) the problems, faced by graduates, include fear of patients; limited access to manipulation due to patients' unwillingness to receive procedures from less experienced specialists; lack of time to train each practical skill.

The low level of professional training of future doctors leads to a high risk to the patient's health. Therefore, the main task of middle and higher medical education is to strengthen the practical training of graduates while maintaining the proper level of theoretical knowledge.

Place and time of the study. In the period from September 14 to October 03, 2020, Cherkasy Medical Academy conducted an online survey of graduate students of specialty 223 Nursing to determine the socio-demographic characteristics of respondents. The second part of the online survey was conducted from March 15 to April 09, 2021 in order to assess applicants' own level of mastering practical skills. The questionnaires were distributed through Google Forms and the Moodle educational platform. Also, during the first and second semesters of the 2020-2021 academic year, the permanent Center for stimulating training of the academy prepared these applicants for professional skills using simulation technologies.

The study was conducted using the following methods:

1) theoretical - generalization of scientific research on the use of simulation training methods in the preparation of specialists with medical education; systematization of the source base, Internet resources, practical experience of the academy;

2) mathematical and statistical methods allowed us to substantiate and graphically present the study results on the effectiveness of the method of simulation tutoring of future medical specialists at the training stage;

Literature review. The analysis of foreign and domestic sources has proved that modern methods of teaching professional skills are the use of simulation technologies, which provide for the creation of training rooms and/or incentive training centers in educational institutions with the appropriate equipment for medical (nursing) manipulations. At the same time, most teachers of medical educational institutions consider it necessary to use models and simulators. However, a number of teachers believe that no modern computer simulator will ever replace working at the patient's bedside, when a student independently performs manipulations under the guidance of a teacher or an experienced specialist of a healthcare institution.

Ukrainian researchers, studying the domestic and foreign experience of stimulating training, consider it one of the ways to ensure the competitiveness of specialists (Artemenko et al., 2015: 67), and the main condition for acquiring clinical professional skills is to create a safe educational environment. They consider objective assessment, the possibility of repeating manipulations, the absence of risk for patients, unlimited access to the learning environment, and the possibility of debriefing to be the advantages of stimulating training. According to medical scientists, since simulation is a powerful learning tool, it can become an addition to traditional teaching methods (Kasyanova and Bodnya, 2017: 14).

T. Kryuchko and co-authors proposed a technology for the formation of professional communication skills in an artificially created environment of professional communication 
(Kryuchko, 2018: 136), and the primary task of the teacher is to acquire coaching skills, which should be taken care of by the system of training teachers for simulation centers.

The use of internationally recognized programs, the solution of organizational and educational issues is proposed by O. Starets when introducing simulation training methods into the educational process (Starets, etc., 2018: 94). At the pre-graduate stage of training, it is considered appropriate to use manipulation protocols (algorithms), in the internship - the formation of communicative competence among applicants, and every five years, during continuous professional development, it is recommended to update the knowledge and skills of emergency medical care.

Simulation tutoring is considered by many authors as the basic platform of modern education (Zhukova et al., 2020: 222), it complements the training of applicants for independent clinical practice, contributes to the formation of their professional competence (Ilashchuk, Mikulets, 2017: 11), increases the interest of applicants in the learning process, becomes an integral part of the professionalism of future specialists and the most optimal form of training in the administering of emergency medical care when working out scenarios (Korda, etc., 2016: 18).

A review of the works of Ukrainian researchers has shown that the modern scientific literature does not sufficiently cover the issues of simulation tutoring in professional education of specialists with incomplete, basic higher and pre-higher education. The authors' attention is focused on the processes of formation of professional training of future specialists with "complete" higher education.

Nevertheless, the analysis of foreign sources revealed the accumulation of extensive experience in using simulation technologies in the education of nurses. Attitude to the profession of a nurse as not an assistant doctor and executor of medical appointments, but as an independent member of the patient care team, the change in the educational vector from medical to nursing education has contributed to an increase in the importance of this profession in society and the medical community.

In particular, the authors note that training nurses based on modeling is a common strategy for improving their skills (Hegland et al., 2017: 6), simulation training can be an element of an individual strategy to improve the quality of healthcare and reduce errors in patient care, so there is a need for quality educational programs to establish which modeling strategy and organization is most effective during the implementation of the educational process.

Evidence suggests that simulation training improves the clinical knowledge and performance of nurses in recognizing and managing clinical deterioration in simulated environments (Chua, 2017: 122). Clinical education in nursing, according to J.H. Kim (Kim et al., 2016), aims to integrate theoretical knowledge from books into practical knowledge in real-world situations and help students develop their skills in solving patient problems. According to the researchers, simulation-based clinical education is a useful pedagogical approach that provides educational applicants with the opportunity to improve their clinical and decision-making skills through a variety of real-world situational experiences without compromising patient safety. The complexity of health systems in different countries puts patient safety at risk (Escudero et al., 2019), therefore, clinical modeling is a very valuable training method aimed at improving patient safety and is an important option for achieving a safety culture.

The purpose of the study of scientists S.A. Mohamed and I.H. Fashafsheh was an assessment of the effect of simulation training on the communication skills and clinical competence of nurses (Mohamed, Fashafsheh, 2019), the results of the study proved that the competence to provide medical and emergency care and communication skills significantly increased in students after participating in the simulation program. 
M. Aebersold, after studying several simulation learning models, notes that simulation (using computerized dummies) has moved to a central stage in nursing education (Aebersold, 2018). Simulation is no longer seen as an "additional component" in mastering nursing programs. It is extremely important in modern education to integrate modeling throughout the entire educational program. Clinical situation modeling and integration into nursing education of high-tech skills modeling (HFS) will effectively provide a safe environment for learning and applying the necessary skills for nursing practice (Onello, Regan, 2013), will contribute to improving individual and leadership skills in a safe environment before meeting with real patients.

\section{Evaluation of training efficiency of the simulation method of future medical specialists at the training stage}

The study of the effectiveness of the simulation tutoring methodology was carried out according to the principle that the simulation tutoring of nurses at the stage of training in an educational institution and in the field of Continuing Professional Education should be specific (technical (manipulative) and non-technical skills) and subject-specific. Also, the training program in nursing disciplines includes basic skills (patient care); skills of medium complexity - monitoring and methods for assessing the patient's condition; non-injection use of drugs; high-tech skills (special training, knowledge of anatomical and topographic features, physiology and pathophysiology, etc.).

The study was conducted during the 2020-2021 academic year from September 14, 2020 to April 09, 2021. The first stage of the study included an online survey of graduate group students of specialty 223 Nursing of the educational qualification level "junior specialist" and the level of education of the first (Bachelor's) in order to determine the socio-demographic characteristics of respondents. Total participants took part in the survey:

- 55 respondents who studied on the basis of basic general secondary education, the duration of study is 4 years;

-19 respondents who studied on the basis of complete general secondary education, the duration of study is 4 years;

-11 respondents who studied on the basis of the educational qualification level "junior specialist", the training period is 1 year.

Thus, according to the level of previous education, the following groups were formed: $64.7 \%$ on the basis of grad $9,22.3 \%$ on the basis of grade $11,13 \%$ on the basis of the educational qualification level "junior specialist" (fig. 1).

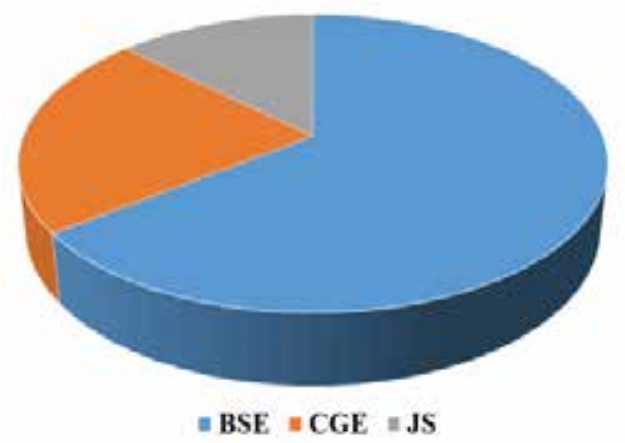

Fig. 1. Distribution of respondents by the level of previous education, as a percentage 
By age, respondents were distributed as follows: 19 years $-45.8 \%$; at the age of $20-$ $32.9 \%$; 21 years $-15.3 \%$; above 22 years $-6 \%$ (fig. 2 ).

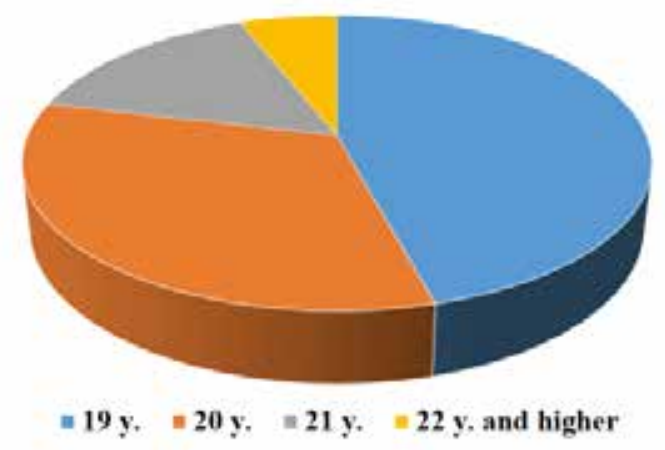

Fig. 2. Distribution of respondents by age, as a percentage

$91.8 \%$ of respondents are female, $8.2 \%$ are male.

The training programs of nursing disciplines provide for the use of simulation techniques: in the first year when studying the discipline fundamentals of Nursing and in the second and third years when studying the disciplines of a special (professional) component. The undergraduate nursing program also includes simulation training modules in clinical nursing disciplines. Simulation tutoring is carried out in the Academy's Simulation Training Center, which is equipped with simulation models and simulators of various levels of complexity: for practicing basic skills - models of 1-4 reality levels, for modeling of clinical high-tech skills (HFS) models of 5-7 reality levels.

Simulation tutoring of nurses at the pre-graduate stage of training is carried out sequentially at the following levels:

1. Theoretical training - visualization)-receiving theoretical training before or after the start of simulation tutoring, demonstrating the manipulations according to protocols, viewing diagrams, video clips, etc.

2 Development of basic skills under the guidance of a mentor (trainer): general (first aid) and nursing skills: is carried out at a tactile level using special equipment (anatomical models, phantoms, simulators) that passively respond to intervention.

3. Performing individual "special" manipulations - requires special training, entails personal responsibility, obliges the educational applicant to perform high-quality procedures; training is carried out on special equipment with the feedback and with the help of special signals informs about the correctness of performed manipulations.

4. Imitation of individual professional activity - is carried out on automated simulators, computers control the correctness of nursing interventions, and the learning process is also accompanied by trainings related to the formation and improvement of activities in general, and not just the acquisition of specific skills; specific skills in this case become a means of solving a professional problem in the course of acquiring their own experience (competence).

5. Simulation of the medical (nursing) team duties - work of a nurse in the manipulation room, operating unit, preparing the patient for surgical interventions and/or for conducting functional studies, etc.; trainings related to the formation and improvement of activities in general are conducted simultaneously. Training takes place in small groups, and the interaction 
of team members in the process of providing patient care becomes important. In the course of training, nurses acquire leadership and communication competencies.

6. "Standardized patient" technology is an interactive technology used before sending students to the practice, a phantom patient simulator is used, which is able to change its functional state, depending on the tasks set.

7. The most difficult level of simulation tutoring is training at the patient's bedside; this stage is carried out in the workplace, without the participation of patients (using mannequins or phantom simulators) using medical equipment, which makes training more productive, and most importantly safe for the patient.

An approximate scheme of nurse simulation training modules is shown in Figure 3.

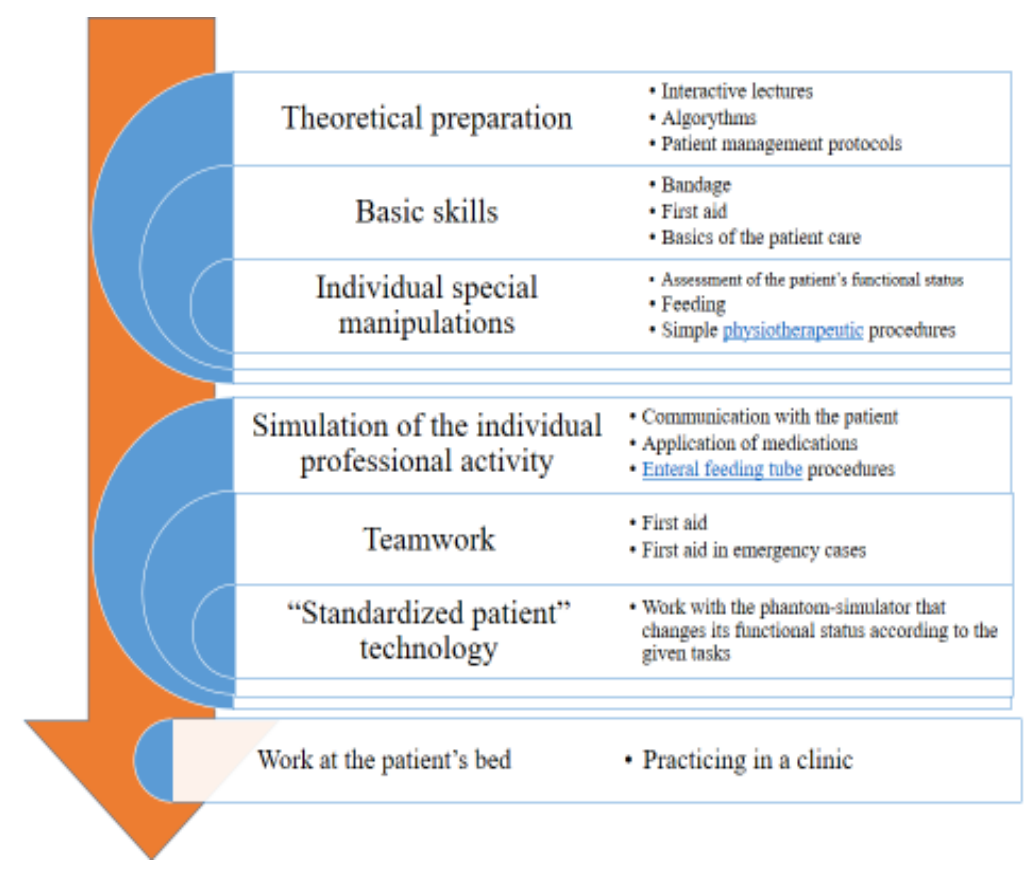

\section{Fig. 3. Sample scheme of stimulation training modules specialty Nursing}

The formation of professional skills in simulation training technologies becomes effective only if nursing interventions are performed consistently, according to certain algorithms, in compliance with the standards of nursing procedures. During the lesson, each student is asked to complete a situational task according to a certain algorithm. Algorithms of nursing interventions consist of general modules: 1) task conditions (information about the intervention and availability of equipment); 2) patient intake; 3) activity (the student's ability to perform the intervention); 4) feedback (information about the result obtained using special functions of the simulator).

The success of each class depends on the following certain conditions: 1) the simulation training program should be built from simple to complex nursing interventions (from the simplest nursing manipulations to high-tech ones);2) the teacher-trainer should analyze individual manipulations causing difficulties for applicants in performing them; 3) simulation 
trainings should not look like monotonous and inactive demonstrations; 4) classes should be built according to a certain plan, in which each subsequent task would organically complement the previous one.

An important stage of simulation training is quality control of the acquired knowledge and practical skills. The training is accompanied by constant monitoring, which is carried out by the teacher. In the course of performing situational tasks, the necessary indicators are recorded and a final assessment is formed at the end. Upon completion of training, assessment control (certification) is carried out in each of the professional disciplines, during which the final tasks are performed and the final assessment is formed based on the results of the points received. The assessment is carried out on a 200-point scale, the National Assessment Scale and the ICTS scale.

According to the results of our observations and the program of professional modules, the most acceptable means of control in the structure of simulationtutoring is the control according to the scheme in four stages: initial, current, intermediate and final. The main purpose of the initial control is to assess the initial level of knowledge and skills of educational applicants, their motivation for the chosen specialty, determine the feasibility of simulation training, identify gaps in theoretical training or in the acquisition of basic skills. Current control is of a corrective and educational value, the formation of target skills and abilities is evaluated, applicants work out a situational task on the simulator, and the trainer monitors the correct execution of manipulations. The main function of the boundary control is observation, assessment, correction, and only partially motivation and training. Assessment is carried out at the end of the module (section) in order to obtain information about the task success and decide on the transition to the next stage of training that is acquiring the next skill. The purpose of the final control is to determine the minimum required level of training. All four stages of control during stimulating tutoring are fully applied and complement each other naturally.

The objectivity of expert assessment is ensured by specially structured assessment checklists filled out by several expert-teachers of clinical departments (table 1).

Table 1

\section{Structured checklist for evaluating the practical skill}

"Subcutaneous injection (insulin administration)"

\begin{tabular}{|l|c|c|c|c|c|}
\hline \multicolumn{1}{|c|}{ Criterion } & \multicolumn{4}{|c|}{ Ratings for each criterion (tick appropriate answer) } \\
\hline \multicolumn{1}{|c|}{1} & 2 & 3 & 4 & 5 & 6 \\
\hline Procedure preparation & Not done & Gross & Done with & Done not & Done \\
Prepare the patient & & mistake & errors & confidently & correctly \\
for manipulation & & $120-149$ & $150-164$ & $165-179$ & $180-200$ \\
psychologically & & points & points & points & points \\
\hline Get consent to perform it & Not done & Gross & Done with & Done not & Done \\
& & mistake & errors & confidently & correctly \\
& & $120-149$ & $150-164$ & $165-179$ & $180-200$ \\
& & points & points & points & points \\
\hline Clarify individual sensitivity & Not done & Gross & Done with & Done not & Done \\
to the drug & & mistake & errors & confidently & correctly \\
& & $120-149$ & $150-164$ & $165-179$ & $180-200$ \\
& & points & points & points & points \\
\hline
\end{tabular}


Table 1 (Continued)

\begin{tabular}{|c|c|c|c|c|c|}
\hline 1 & 2 & 3 & 4 & 5 & 6 \\
\hline Підготувати оснащення & Not done & $\begin{array}{l}\text { Gross } \\
\text { mistake } \\
120-149 \\
\text { points }\end{array}$ & $\begin{array}{l}\text { Done with } \\
\text { errors } \\
150-164 \\
\text { points }\end{array}$ & $\begin{array}{l}\text { Done not } \\
\text { confidently } \\
165-179 \\
\text { points }\end{array}$ & $\begin{array}{l}\text { Done } \\
\text { correctly } \\
180-200 \\
\text { points }\end{array}$ \\
\hline $\begin{array}{l}\text { Wash your hands under } \\
\text { running water twice with } \\
\text { soap, dry them with a paper } \\
\text { or individual towel, and } \\
\text { treat them with alcohol or } \\
\text { hand sanitizer }\end{array}$ & Not done & $\begin{array}{l}\text { Gross } \\
\text { mistake } \\
120-149 \\
\text { points }\end{array}$ & $\begin{array}{l}\text { Done with } \\
\text { errors } \\
150-164 \\
\text { points }\end{array}$ & $\begin{array}{l}\text { Done not } \\
\text { confidently } \\
165-179 \\
\text { points }\end{array}$ & $\begin{array}{l}\text { Done } \\
\text { correctly } \\
180-200 \\
\text { points }\end{array}$ \\
\hline Wear a mask and gloves & Not done & $\begin{array}{l}\text { Gross } \\
\text { mistake } \\
120-149 \\
\text { points }\end{array}$ & $\begin{array}{l}\text { Done with } \\
\text { errors } \\
150-164 \\
\text { points }\end{array}$ & $\begin{array}{l}\text { Done not } \\
\text { confidently } \\
165-179 \\
\text { points }\end{array}$ & $\begin{array}{l}\text { Done } \\
\text { correctly } \\
180-200 \\
\text { points }\end{array}$ \\
\hline $\begin{array}{l}\text { Check the label on the } \\
\text { package with the treatment } \\
\text { sheet (name, concentration, } \\
\text { quantity, expiration date) }\end{array}$ & Not done & $\begin{array}{l}\text { Gross } \\
\text { mistake } \\
120-149 \\
\text { points }\end{array}$ & $\begin{array}{l}\text { Done with } \\
\text { errors } \\
150-164 \\
\text { points }\end{array}$ & $\begin{array}{l}\text { Done not } \\
\text { confidently } \\
165-179 \\
\text { points }\end{array}$ & $\begin{array}{l}\text { Done } \\
\text { correctly } \\
180-200 \\
\text { points }\end{array}$ \\
\hline $\begin{array}{l}\text { Performing the procedure } \\
\text { Prepare an insulin syringe } \\
\text { and an insulin vial before } \\
\text { performing the injection. } \\
\text { Collect insulin from the } \\
\text { bottle (after wiping the } \\
\text { rubber cap with alcohol, } \\
\text { let the alcohol dry) in } \\
\text { accordance with the } \\
\text { prescribed dose, taking into } \\
\text { account that } 1 \text { ml contains } \\
40 \text { or } 100 \text { units of insulin } \\
\text { (check with the bottle) }\end{array}$ & Not done & $\begin{array}{l}\text { Gross } \\
\text { mistake } \\
120-149 \\
\text { points }\end{array}$ & $\begin{array}{l}\text { Done with } \\
\text { errors } \\
150-164 \\
\text { points }\end{array}$ & $\begin{array}{l}\text { Done not } \\
\text { confidently } \\
165-179 \\
\text { points }\end{array}$ & $\begin{array}{l}\text { Done } \\
\text { correctly } \\
180-200 \\
\text { points }\end{array}$ \\
\hline $\begin{array}{l}\text { Help the patient take a } \\
\text { comfortable position }\end{array}$ & Not done & $\begin{array}{l}\text { Gross } \\
\text { mistake } \\
120-149 \\
\text { points } \\
\end{array}$ & $\begin{array}{l}\text { Done with } \\
\text { errors } \\
150-164 \\
\text { points } \\
\end{array}$ & $\begin{array}{c}\text { Done not } \\
\text { confidently } \\
165-179 \\
\text { points } \\
\end{array}$ & $\begin{array}{c}\text { Done } \\
\text { correctly } \\
180-200 \\
\text { points } \\
\end{array}$ \\
\hline $\begin{array}{l}\text { Wipe the injection site twice } \\
\text { with cotton balls soaked in } \\
\text { alcohol, let the alcohol dry }\end{array}$ & Not done & $\begin{array}{l}\text { Gross } \\
\text { mistake } \\
120-149 \\
\text { points }\end{array}$ & $\begin{array}{l}\text { Done with } \\
\text { errors } \\
150-164 \\
\text { points }\end{array}$ & $\begin{array}{l}\text { Done not } \\
\text { confidently } \\
165-179 \\
\text { points }\end{array}$ & $\begin{array}{l}\text { Done } \\
\text { correctly } \\
180-200 \\
\text { points }\end{array}$ \\
\hline $\begin{array}{l}\text { Treat your hands with } \\
\text { alcohol }\end{array}$ & Not done & $\begin{array}{l}\text { Gross } \\
\text { mistake } \\
120-149 \\
\text { points }\end{array}$ & $\begin{array}{l}\text { Done with } \\
\text { errors } \\
150-164 \\
\text { points }\end{array}$ & $\begin{array}{l}\text { Done not } \\
\text { confidently } \\
165-179 \\
\text { points }\end{array}$ & $\begin{array}{l}\text { Done } \\
\text { correctly } \\
180-200 \\
\text { points }\end{array}$ \\
\hline $\begin{array}{l}\text { Remove any remaining air } \\
\text { from the syringe }\end{array}$ & Not done & $\begin{array}{l}\text { Gross } \\
\text { mistake } \\
120-149 \\
\text { points } \\
\end{array}$ & $\begin{array}{l}\text { Done with } \\
\text { errors } \\
150-164 \\
\text { points } \\
\end{array}$ & $\begin{array}{l}\text { Done not } \\
\text { confidently } \\
165-179 \\
\text { points }\end{array}$ & $\begin{array}{c}\text { Done } \\
\text { correctly } \\
180-200 \\
\text { points } \\
\end{array}$ \\
\hline
\end{tabular}


Table 1 (Continued)

\begin{tabular}{|c|c|c|c|c|c|}
\hline 1 & 2 & 3 & 4 & 5 & 6 \\
\hline $\begin{array}{l}\text { Grasp the subcutaneous skin } \\
\text { at the injection site with the } \\
\text { index finger and thumb of } \\
\text { the left hand }\end{array}$ & Not done & $\begin{array}{c}\text { Gross } \\
\text { mistake } \\
120-149 \\
\text { points }\end{array}$ & $\begin{array}{l}\text { Done with } \\
\text { errors } \\
150-164 \\
\text { points }\end{array}$ & $\begin{array}{c}\text { Done not } \\
\text { confidently } \\
165-179 \\
\text { points }\end{array}$ & $\begin{array}{c}\text { Done } \\
\text { correctly } \\
180-200 \\
\text { points }\end{array}$ \\
\hline $\begin{array}{l}\text { Insert a needle into the base } \\
\text { of the formed fold for } 2 / 3 \\
\text { of its length at an angle of } \\
30-45^{\circ}\end{array}$ & Not done & $\begin{array}{c}\text { Gross } \\
\text { mistake } \\
120-149 \\
\text { points }\end{array}$ & $\begin{array}{l}\text { Done with } \\
\text { errors } \\
150-164 \\
\text { points }\end{array}$ & $\begin{array}{c}\text { Done not } \\
\text { confidently } \\
165-179 \\
\text { points }\end{array}$ & $\begin{array}{c}\text { Done } \\
\text { correctly } \\
180-200 \\
\text { points }\end{array}$ \\
\hline $\begin{array}{l}\text { Release the crease and } \\
\text { slowly inject the medicine }\end{array}$ & Not done & $\begin{array}{c}\text { Gross } \\
\text { mistake } \\
120-149 \\
\text { points }\end{array}$ & $\begin{array}{l}\text { Done with } \\
\text { errors } \\
150-164 \\
\text { points }\end{array}$ & $\begin{array}{c}\text { Done not } \\
\text { confidently } \\
165-179 \\
\text { points }\end{array}$ & $\begin{array}{c}\text { Done } \\
\text { correctly } \\
180-200 \\
\text { points }\end{array}$ \\
\hline $\begin{array}{l}\text { Apply a dry sterile cotton } \\
\text { swab to the injection site }\end{array}$ & Not done & $\begin{array}{c}\text { Gross } \\
\text { mistake } \\
120-149 \\
\text { points } \\
\end{array}$ & $\begin{array}{l}\text { Done with } \\
\text { errors } \\
150-164 \\
\text { points } \\
\end{array}$ & $\begin{array}{c}\text { Done not } \\
\text { confidently } \\
165-179 \\
\text { points } \\
\end{array}$ & $\begin{array}{c}\text { Done } \\
\text { correctly } \\
180-200 \\
\text { points } \\
\end{array}$ \\
\hline $\begin{array}{l}\text { Pull out the needle with a } \\
\text { quick movement }\end{array}$ & Not done & $\begin{array}{c}\text { Gross } \\
\text { mistake } \\
120-149 \\
\text { points }\end{array}$ & $\begin{array}{l}\text { Done with } \\
\text { errors } \\
150-164 \\
\text { points }\end{array}$ & $\begin{array}{c}\text { Done not } \\
\text { confidently } \\
165-179 \\
\text { points }\end{array}$ & $\begin{array}{c}\text { Done } \\
\text { correctly } \\
180-200 \\
\text { points }\end{array}$ \\
\hline $\begin{array}{l}\text { Ask the patient about } \\
\text { general state }\end{array}$ & Not done & $\begin{array}{c}\text { Gross } \\
\text { mistake } \\
120-149 \\
\text { points }\end{array}$ & $\begin{array}{l}\text { Done with } \\
\text { errors } \\
150-164 \\
\text { points }\end{array}$ & $\begin{array}{c}\text { Done not } \\
\text { confidently } \\
165-179 \\
\text { points }\end{array}$ & $\begin{array}{c}\text { Done } \\
\text { correctly } \\
180-200 \\
\text { points }\end{array}$ \\
\hline $\begin{array}{l}\text { End of the procedure } \\
\text { Disinfect used equipment }\end{array}$ & Not done & $\begin{array}{c}\text { Gross } \\
\text { mistake } \\
120-149 \\
\text { points }\end{array}$ & $\begin{array}{l}\text { Done with } \\
\text { errors } \\
150-164 \\
\text { points }\end{array}$ & $\begin{array}{c}\text { Done not } \\
\text { confidently } \\
165-179 \\
\text { points }\end{array}$ & $\begin{array}{c}\text { Done } \\
\text { correctly } \\
180-200 \\
\text { points }\end{array}$ \\
\hline Wash and dry your hands & Not done & $\begin{array}{c}\text { Gross } \\
\text { mistake } \\
120-149 \\
\text { points }\end{array}$ & $\begin{array}{l}\text { Done with } \\
\text { errors } \\
150-164 \\
\text { points }\end{array}$ & $\begin{array}{c}\text { Done not } \\
\text { confidently } \\
165-179 \\
\text { points } \\
\end{array}$ & $\begin{array}{c}\text { Done } \\
\text { correctly } \\
180-200 \\
\text { points }\end{array}$ \\
\hline $\begin{array}{l}\text { Make a record of the } \\
\text { procedure and the patient's } \\
\text { response to it in the relevant } \\
\text { medical documentation }\end{array}$ & Not done & $\begin{array}{c}\text { Gross } \\
\text { mistake } \\
120-149 \\
\text { points }\end{array}$ & $\begin{array}{l}\text { Done with } \\
\text { errors } \\
150-164 \\
\text { points }\end{array}$ & $\begin{array}{c}\text { Done not } \\
\text { confidently } \\
165-179 \\
\text { points }\end{array}$ & $\begin{array}{c}\text { Done } \\
\text { correctly } \\
180-200 \\
\text { points }\end{array}$ \\
\hline
\end{tabular}

In order to evaluate complex skills combining teamwork, clinical thinking, knowledge and skills, an integrated objective assessment is used on the basis of the virtual systems and robot simulators of the patient. The information forming system for the final assessment (compliance of an educational applicant with the requirements of the educational standard in the specialty) should take into account the data of testing theoretical knowledge, professional skills and the results of expert assessment.

The second stage of the online survey of applicants for final courses of the specialty nursing was conducted at the end of the second semester before students began to enter a pre-graduate practice. For this purpose, a questionnaire with the following questions was developed: 
a) whether applicants are satisfied with the quality of education received and whether they believe that the knowledge gained during the years of study at the academy will help them to provide better care to patients; 2) how do you assess the effectiveness of the simulation training methodology and the knowledge, skills and abilities you have gained during training on the basis of the Simulation Training Center; 3) whether you have received enough knowledge to analyze clinical syndromes, justify the methods/principles of diagnosis, treatment, prevention within the nursing process.

The analysis of knowledge quality assessment is shown in Figure 4.

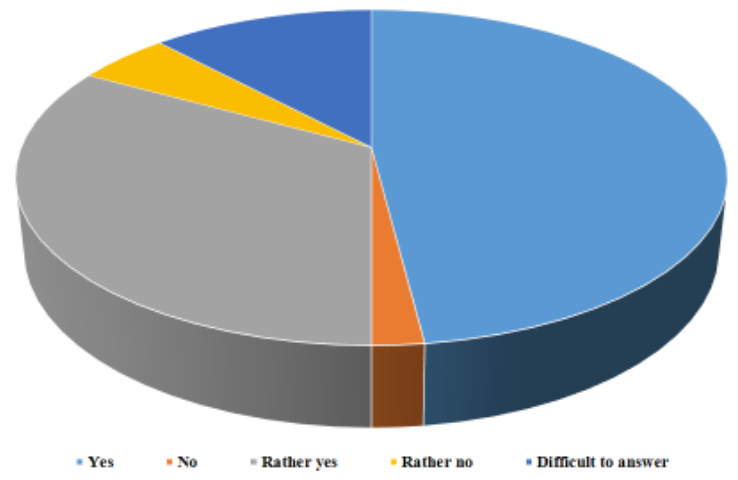

Fig. 4. Respondents' answers to the question: "Are applicants satisfied with the quality of education received and does the education received contribute to better provision of medical services?"

The results of the survey indicate that nursing as a specialty is gradually taking a stable place in the structure of medical personnel training, it is interesting and promising, as proven by the fact that $81 \%$ of applicants are generally satisfied with the quality of Education received and believe that the professional knowledge and skills obtained during the years of study at the academy will help to provide better care to patients, $7 \%$ of applicants have not yet decided on their future profession, $12 \%$ did not answer, which most likely means that they have not determined the essence of the activities that they will be engaged in in the future.

Evaluation of the effectiveness of the simulation tutoring methodology and the acquired knowledge and skills during training on the basis of the Simulation Training Center provided with the following results (fig. 5).

Thus, the majority of students $58 \%$ consider the methodology of simulation tutoring based on the Simulation Training Center effective, $37 \%$ of students are generally satisfied with the teaching methodology and received the necessary basis for future professional activity that meets their needs and expectations.

The question "Do you have enough knowledge to analyze clinical syndromes, justify methods/principles of diagnosis, treatment, prevention in the nursing process" got the following answers: $78 \%$ of respondents answered positively, 3\% gave a negative answer, $19 \%$ of respondents generally received enough knowledge and are able to either start or continue their professional development within the chosen specialty. 


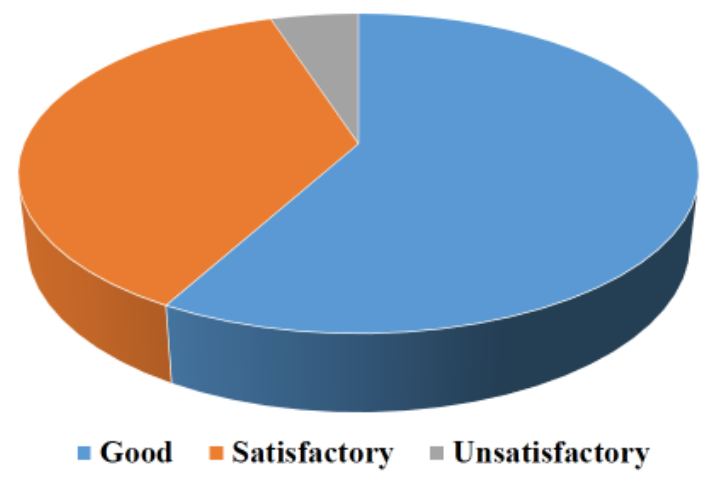

Fig. 5. Respondents' answers to the question: "How do you assess the effectiveness
of the simulation training methodology?"

\section{Conclusions}

The conducted research proves that the main tasks of simulation tutoring are solved when using models of 4-7 reality levels. Creating clinical situations close to real life in stimulation training centers and training rooms, improving practical manipulations in conditions close to real life, modern equipment, a dummy (or volunteer) that independently responds to the intern's intervention, contributes to improving the professional level of nurses and their readiness to apply knowledge and skills in clinical practice. Students under the guidance of a teacher-trainer, through repeated repetition and analysis of mistakes, achieve the desired level of preparation for working with equipment, patient, team, master general and professional competencies. When forming educational programs in the specialty of Nursing, it is necessary to provide for simulation tutoring of applicants for education in professional clinical disciplines, alternate the stages of traditional training with simulation and control tools with the assessment of skill level indicators when moving from one module to the next. In order to increase the effectiveness of simulation tutoring, it is necessary to ensure re-education both in the process of direct (pre-graduate) training of nurses, and in the system of continuing professional education.

\section{References}

Aebersold, M. (2018). Simulation-Based Learning: No Longer a Novelty in Undergraduate Education. OJIN: The Online Journal of Issues in Nursing Vol. 23, № 2. https://doi.org/10.3912/ OJIN. Vol23No02PPT39.

Artyomenko, V.V., Semchenko, S. S., Yehorenko, O. S., Novikov, D. A., Karakonstantin, D. F., Berlinska, L. S. (2015). Symuliatsiine navchannia v medytsyni: mizhnarodnyi ta vitchyznianyi dosvid [Simulation Medical Education: International and National Experience]. Ohliady, № 6 (152). Odesa [in Ukrainian]

Chua, W L. (2017). Simulation training appears to improve nurses ability to recognise and manage clinical deterioration. Evid Based Nurs, Vol. 20, № 4, 122-123. http://doi.org/10.1136/ eb-2017-102742 
Escudero, E., Silva, M., Corvetto, M. (2019). Simulation: A Training Resource for Quality Care and Improving Patient Safety. Nursing - New Perspectives, Serpil Çelik Durmus, IntechOpen, http://doi.org/10.5772/intechopen.88918.

Hegland, P.A., Aarlie, H., Stromme, H., Jamtvedt, G. (2017) Simulation-based training for nurses: Systematic review and meta-analysis. Nurse Education Today, Vol. 54, 6-20. https:// doi.org/10.1016/j.nedt.2017.04.004

Ilashchuk, T.O., Mikulets, L.V. (2017). Symuliatsiini tekhnolohii navchannia pry vyvchenni propedevtyky vnutrishnikh khvorob [Simulation Learning Technologies During Study Propaedeutic of Internal Diseases]. Medychna osvita, № 2, 9-11. http://doi.org/10.11603/ me.2414-5998.2017.2.7882. [in Ukrainian]

Kasyanova, O.M., Bodnya, K.I. (2017). Symuliatsiine navchannia v pisliadyplomnii medychnii osviti: teoretychnyi i praktychnyi aspekty [Simulation Training in Postgraduate Medical Education: Theoretical and Practical Aspects]. Problemy bezperervnoi medychnoi osvity i nauky, № 1, 10-15. [in Ukrainian]

Kim, JH., Park, J-H., Shin, S. (2016). Effectiveness of simulation-based nursing education depending on fidelity: a meta-analysis. BMC Med Educ 16, 152. https://doi.org/10.1186/ s12909-016-0672-7

Korda, M. M., Shulhai, A. H., Zaporozhan, S. Y., Kritsak, M. Yu. (2016). Symuliatsiine navchannia u medytsyni - skladova chastyna u protsesi pidhotovky likaria-spetsialista [Simulating Learning in Medicine Part in the Preparation of a Specialist]. Medychna osvita, № 4, 17-20. http://doi.org/10.11603/me.2414-5998.2016.4.7302. [in Ukrainian]

Kriuchko, T.O., Kushnereva T.V., Kharshman V.P. (2018). Metodolohiia stymuliatsiinoho navchannia. [Methodology of Stimulating Training] Aktualni pytannia kontroliu yakosti osvity $u$ vyshchykh medychnykh navchalnykh zakladakh. VDNZ Ukrainy "Ukrainska medychna stomatolohichna akademiia», 136-137 Poltava. Available from: http://elib.umsa.edu.ua/jspui/ bitstream/umsa/8533/1/70_MSN.pdf [in Ukrainian]

Mohamed, S.A., Fashafsheh, I.H. (2019). The Effect of Simulation-Based Training on Nursing Students Communication Skill, Self-Efficacy and Clinical Competence for Nursing Practice. Open Journal of Nursing, 9, 855-869. https://doi.org/10.4236/ojn.2019.98064

Onello, R., Regan, M. (2013). Challenges in High Fidelity Simulation: Risk Sensitization and Outcome Measuremen. OJIN: The Online Journal of Issues in Nursing, Vol. 1, № 3. https:// doi.org/10.3912/OJIN. Vol18No03PPT01

Starets, O.O., Kotova, N.V., Loseva, K.O., Fedorenko, O.V. (2018). Dosvid vprovadzhennia symuliatsiinoho navchannia i universalnoho pidkhodu do otsinky, rozpiznavannia ta stabilizatsii staniv, shcho zahrozhuiut zhyttiu dytyny. [Experience of the Implementation of Simulation Learning and a Universal Approach to Assessing, Recognizing and Stabilizing Life-threatening Conditions in Children]. Clinical Anesthesiology \& Intensive Care, № 1 (11). http:// doi.org/10.31379/2411.2616.11.1.7. [in Ukrainian]

Zhukova, T. O., Vasko, L. M., Pocherniaieva, V. F., Marchenko, V. Yu., Udaltsova-Hrodzynska, K. O. (2020). Symuliatsiini treninhy, yak bazova platforma suchasnoi osvity [Simulation Training as a Basic Platform of Modern Education]. Visnyk problem biolohii i medytsyny, Vyp. 4 (158), 222-224. http://doi.org/ 10.29254/2077-4214-2020-4-158-222-224. [in Ukrainian] 